\title{
RESENHA
}

\section{Inserção Internacional: formação dos conceitos brasileiros*}

JOSÉ FLÁVIO SOMBRA SARAIVA**

Eis uma criativa reflexão nacional, essencial às comemorações que se aproximam do centenário da disciplina dedicada ao estudo das relaçóes internacionais. O livro de Amado Luiz Cervo inova ao sistematizar conhecimento brasileiro essencial à formação de conceitos em relações internacionais.

O argumento central do autor é que o Brasil, ao lado de uma dezena de países, propõe conceitos próprios a essa área do conhecimento, tanto quanto próprias são as concepções dos demais centros de produção científica para o estudo das relações internacionais em outras regiōes do mundo. A espinha dorsal do livro situa-se no diálogo do pensamento brasileiro com os conhecimentos disponíveis na conformação epistemológica da disciplina. Situa Cervo o Brasil como uma nação de experiência singular ao fazer "de si idéia própria do papel a desempenhar no mundo". Utilíssimo à grande área voltada para o estudo dos vínculos entre sociedades nacionais e o meio internacional, o autor se inspira no ambiente acadêmico brasileiro e latino-americano, e também na história acumulada pela prática diplomática brasileira bem como pela trajetória do Estado nacional.

Para Cervo, um feixe de conceitos articulados a um objeto fornece base para uma teoria. Daí o livro ser, de fato, uma obra com ambição teórica. Em um país que, nos anos 1990, tanto se acostumou a copiar teorias alheias e aplicá-las, de forma pouco crítica, à experiência internacional do Brasil, a contribuição do grande scholar brasileiro é um marco na sistematização para fins aplicativos do pensamento brasileiro de relações internacionais. O título já indica o rumo da obra ao reivindicar o conceito de inserção internacional, urdido e irradiado a partir da experiência brasileira, mas também em parte da América Latina.

Apesar de antecedentes que remontam a Tucídides, as relaçôes internacionais se estabeleceram como disciplina acadêmica apenas no século XX, abalado pela guerra de 1914-1918 e por internacionalização econômica, política e cultural. Da crise da hegemonia européia à formação da Guerra Fria, passando pela

\footnotetext{
* CERVO, Amado Luiz. Inserção Internacional: formação dos conceitos brasileiros. São Paulo: Editora Saraiva, 2008, 297 p., ISBN 978-85-02-06570-3.

** Professor do Instituto de Relações Internacionais da Universidade de Brasília UnB, diretor-geral do Instituto Brasileiro de Relaçôes Internacionais - IBRI e bolsista de produtividade em pesquisa do Conselho Nacional de Desenvolvimento Científico e Tecnológico - CNPq.
} 
planetarização da vida internacional, foram esses contextos que moldaram a nova área científica, institucionalmente organizada desde universidades européias e norte-americanas.

O léxico e a formação dos conceitos hegemônicos da disciplina, em grande parte, emanaram de referências históricas do nosso tempo: o impacto da dualidade guerra e paz, o peso da internacionalização inédita de regras e valores, a força dos interesses que passaram a vigorar, os desafios das políticas exteriores dos Estados nacionais, a inovação da ampliação de atores internacionais, as dimensôes culturais e identitárias para além do realismo clássico ou do internacionalismo liberal.

A produção de conceitos na área de relações internacionais foi, portanto, controlada pelo quadro referencial e cultural que reproduziu e manteve o controle hegemônico do mundo. Vejam-se as teorias norte-americanas e seus limites cognitivos para o entendimento das novas dinâmicas globais do início do século XXI.

A maneira pela qual a obra de Cervo é encaminhada corre contra a obsoleta importação do abecedário teórico que nutre grande parte das escolas brasileiras de relaçôes internacionais em favor do esforço de pensar as relaçōes internacionais contemporâneas desde o Brasil. Apresenta um livro típico da maturidade dos mestres, com os pés firmes na experiência brasileira de acumulação de idéias e conceitos voltados para a inserção internacional do país. Seu esforço, no entanto, não se inscreve no ambiente do nacionalismo teórico. Ao contrário, é proposta de alcance largo e grande universalidade. É possível imaginar, na leitura de Cervo, a necessidade urgente de estudos assemelhados com enfoque em países hoje com grande presença na cena internacional como a China, a Índia, a Rússia e mesmo a África do Sul. Sabe-se que são também países com contribuiçôes conceituais próprias aos estudos das relaçôes internacionais.

O livro está divido em três partes. Na primeira, dedica-se o autor à formação dos conceitos, ao estudo das transições e à elucidação dos paradigmas históricos que presidem a evolução do lugar do Brasil no mundo nos últimos duzentos anos. Sua estrutura é categorial e sistemática. Utiliza a base social histórica da construção dos conceitos, ora parecendo que é uma elaboração apenas do autor, ora fazendo ver que a elaboração está calcada na idéia que o Brasil faz de si.

É neste quadro que alerta Cervo para o fato de o pensamento brasileiro ter ido bastante além dos velhos horizontes cepalinos e da teoria mecânica centroperiferia provida pelos teóricos da dependência. Insiste que o Brasil desenvolveu raciocínios e práticas voltadas para a busca de brechas, para reduzir o fosso entre os ricos e o Brasil. Mas não deixa de lembrar o autor que um mundo cooperativo entre países desenvolvidos e aspirantes perpetuou-se no ideário brasileiro como uma viga mestra do pensamento nacional aplicado às relações internacionais.

O acumulado histórico da diplomacia brasileira ganha ênfase na formação de conceitos brasileiros. Diretrizes como o não-confrontacionismo, o universalismo, o pacifismo, o zelo pela soberania em razão do papel indutor do Estado e da 
necessidade de planejar o desenvolvimento embalaram concepçôes do agir em situaçōes difíceis, como as de hoje.

Sua crítica à noção ideologizada da globalização do fim do século XX é clara: reduziu a margem de manobra no mundo e infantilizou a nação. A retomada do paradigma logístico, posto em marcha nos últimos anos, reforça a noção criativa da autonomia decisória da política exterior e da implementação de novo modelo pós-desenvolvimentista, no qual, enfim, Estado e sociedade comandam unidos a inserção internacional. Como lembra o autor, a superação de assimetrias entre as naçôes e a elevação do patamar nacional ao nível das nações avançadas tornam-se o escopo final. A conduta logística, porém, não diferencia mais o Brasil dos países avançados, como ocorria no passado.

Descolando-se da teoria estruturalista e se aproximando de visões do realismo histórico, argumenta o autor que o comportamento do Estado logístico move a fase desenvolvimentista para um novo modelo da internacionalização econômica do Brasil. Meios de poder, vantagens comparativas, entre outros fatores, são para Cervo, definidores do paradigma do Estado logístico.

A segunda parte do livro, organizada em torno de quatro capítulos, avança o esforço conceitual anterior, na direção do estudo do Brasil ante à globalização, ao multilateralismo, à segurança, à formação de blocos e às relações inter-societárias. Ganha força, em especial, a discussão do autor em torno da idéia brasileira de multilateralismo e do retorno ao realismo prático, mais responsável em matéria de segurança, defesa e política exterior.

Ainda nessa parte do livro, desenvolve o autor a formação do pensamento integracionista do Brasil e suas aplicações às realidades regionais. $\mathrm{O}$ peso da transformação do Brasil, nas últimas décadas, em um país de emigração, e a busca de capacidades na área científica e tecnológica, demonstram a preocupação do autor em incluir, na formação dos conceitos brasileiros, a força das relações intersocietárias.

$\mathrm{Na}$ terceira e última parte do livro, organizada em seis capítulos, são avaliadas as bases mentais e culturais das relações do Brasil com seus vizinhos, os paradigmas dominantes nessas relações, a parceria estratégica com os Estados Unidos, as relaçôes triangulares, o lugar da Rússia, do Japão, da China, da Índia, do Oriente Próximo e da África na inserção internacional do Brasil. Aplicam-se os conceitos desenvolvidos nas duas partes anteriores por meio da análise paradigmática e de idéias como relações cíclicas, relações em eixo, parcerias estratégicas e estruturas hegemônicas, todas retiradas da experiência brasileira de tratar e conceber o meio internacional via ecumenismo exemplar.

A nova obra de Cervo desnuda, portanto, a inocência conveniente das teorias acerca das relações internacionais do Brasil criadas de fora para dentro. A proposta de Cervo é telúrica, produzida desde um conjunto de valores, padrões de conduta e interesses em torno dos quais o Brasil vem construindo seu lugar no mundo. O alcance explicativo de sua teoria está, portanto, na adequada parcialidade dos 
teóricos que, sem negar seu ponto de partida, buscam vincular e sistematizar a contribuição brasileira ao pensamento das relações internacionais como disciplina acadêmica mais universal.

A formação dos conceitos brasileiros aplicados às relações internacionais agrega, em suma, quatro componentes em sua produção: a reflexão do autor, uma construção social - de pensadores, diplomatas e acadêmicos -, a historicidade que lhes acrescenta consistência e, não menos importante, um valor positivo que transmitem ao leitor e ao tomador de decisão. 